\title{
INVESTIGATION OF CONTROL MEASURES FOR WHITE GRUBS AFFECTING SUGAR CANE IN QUEENSLAND
}

By J. F. Ildivgwonth, Gordontale, near Cairns, North Queensland

After two years of this investigation I am more and more impressed with the tremendous importance of the problem. Furthermore, I appreciate that any successful methods of control should have a farreaching importance; for in many sugar-growing countries, as the newer areas are opened up, these insects appear to be on the increase.

Investigation of control measures for white grubs injurious to field crops is as old as Economic Entomology-more than thirty years ago we find that these pests were a serious menace in Europe. When the cockchafer appeared in Denmark in 1887 the government got behind a movement for collecting the beetles by hand, which was carried out so persistently and economically by the people that the country was apparently quickly rid of the pest. Naturally similar methods have formerly been advocated for Queensland, and, in some localities vast quantities of the beetles were collected, at great expense to the growers; but with little apparent result. The only explanation that suggests itself is that areas collected were comparatively small and the price demanded for collecting would bankrupt a state, if all the beetles were collected. These insects are indigenous on the wild grassland, which is very extensive in North Queensland-much more so than the narrow belts of cleared agricultural lands. It appears to me, something like a proposition of picking up all the insects on a square foot, in the middle of a large field, then expecting that this small area would be freed of the pest for succeeding crops. We get the same result-the beetles swarm over it again from the surrounding infested lands, so that no noticeable benefit appears.

\section{Damage Done by Grubs}

An estimation of the vast economic importance of this pest in North Queensland is difficult to formulate. First of all, we should consider the immense areas which have gone out of cultivation, solely because of the grubs. On the friable red-volcanic soils, which are of high fertility, this is particularly true. Even much of the land that is now planted to cane will soon go out, unless some relief is furnished. The most distressing part of the situation is that the grubs wait until all the work of planting, chipping and cultivation is finished, and the cane is laid by - all the expense has been put into it - when the grubs begin their devastation. It is heartrending to view the ruin on an estate like Greenhills in the Cairns district, where hundreds of acres of beautiful, 
perfect cane goes down to destruction within a few weeks, during March. Once the roots are eaten off, the slightest wind pushes the stools over in that loose soil; then deterioration quickly sets in.

In 1911, a conservative estimate ${ }^{1}$ of the annual loss in the Cairns district, through grubs, was 25 to 30 thousand tons; and this loss continued year after year in spite of all efforts to combat the pest. In one year the Cairns growers collected 22 tons of beetles and 9 tons of grubs, at an expense of over $£ 3000$; with no apparent diminution in the pest. On this point the following interesting figures ${ }^{2}$ will help one to understand what a ton of beetles represent: One pound of beetles equals 250 ; in one ton there are 560,000 beetles, 60 per cent females equals 336,000 each laying eggs which produce 25 fully grown grubs equals $8,400,000$. Since it is estimated that 16,000 grubs are sufficient to destroy one acre of cane; one ton of beetles, therefore, could destroy about 500 acres of cane.

From data at hand, it is easy to see that in all the cane-growing districts of Queensland, the losses from the grub pest alone undoubtedly run into hundreds of thousands of pounds.

\section{Combating the Pest}

I must admit that the problem seemed hopeless at first; but I am beginning to see light. In fact, I am more and more encouraged as the investigation proceeds.

Control measures have been developed along several lines, the most important of which are: (1) stimulating vigour in the plant, (2) egg-destruction by cultivation, (3) application of poison, and, (4) removal of feeding-trees.

There are numerous factors which bring about increased vigour, and all of them should be considered as valuable aids in combating the pest, for if the cane is in a thrifty growing condition it will resist the grubs to a considerable degree. Among these factors, I would suggest, the application of lime and fertilizers, supplying humus, and thorough cultivation.

Lime, as every grower knows, improves the physical condition of clay soils, and assists in the rapid change of plant-refuse into humus. It improves the health of soil bacteria and fungi, in other words, which are all-important in the growing of crops. It is well recognized, too, that a leguminous green-crop does very poorly on land without lime, which is essential to the bacteria forming the nitrifying nodules on the roots.

The use of fertilizers is important to the growing of any crop, but

${ }^{1}$ Aust. Sugar Journal, Vol, 3, p. 199.

2 Aust. Sugar Journal, Vol. 2, p. 443. 
this is particularly true with sugar cane, for experiments have demonstrated that a 30-ton crop removes from the soil 102 pounds of nitrogen, 65 pounds of potash and 45 pounds of phosphate. Land poor in these elements naturally produces cane of inferior quality, which easily succumbs to grub injury. Experience has shown, that for best results, small experimental plots should be developed in each locality, or class of soil. In Hawaii this diversified testing is done by the Planters' Experiment Station, with such efficiency that they have found that under certain conditions it pays to apply 1,200 pounds of mixed fer. tilizers, containing 11 per cent of nitrogen, and on top of this, to add as much as 500 pounds of sulphate of ammonia or nitrate of soda. That is to say, the idea is to apply as much fertilizer as will produce a profit. They also use lime freely. It is by such methods that the output of these small islands has been increased from 75,000 to over 600,000 tons of sugar, in the history of the Station.

Comparatively speaking, little fertilizer is used in Queensland; many of the newer farms get none at all. Consequently, I wish to emphasize not only the value of manures as a factor in grub-control, but further to say that under scientific application they will pay a handsome profit on most soils.

Speaking generally, grubby-soils are lacking in humus. This is true of all of those that I have tested. Experiments have demonstrated that the grubs prefer partly decayed organic matter to living roots. As a matter of fact, they live happily, and develop well in rich soil alone, even when all roots, trash, etc., are removed. Moreover, it is a well-known fact that their bodies are always full of earth during the feeding period; and from this they derive their principal supply of nutriment, by extracting the humus, if present.

Where soils are poor in humus, and all organic matter is removed by the destructive methods of farming now in vogue in Queensland, the grubs are compelled to feed upon the living roots or starve. Furthermore, we know that humus has a remarkable affinity for arsenic, which may be made use of, as I shall point out, later.

What is needed is a method of conserving all trash, and waste from the crop, together with a regular rotation of green-crops. Sooner or later all farms must come under this practice, if the productivity of the land is to be maintained. In line with this advice, I wish to call attention to the large areas at Goondi-the Mundoo section, which produced splendid crops of cane for a few years, but now, is said to be so worn out that it will not pay to work. Apparently many other cane areas are fast approaching this condition, even though only a very few crops have been taken off.

I have emphasized surface cultivation mainly because of its value for 
increasing the vigour of the crop, and in this way making the plants more resistant to attack. However, as I shall indicate later, I have found that it often has a more direct action in the destruction of the pest.

Undoubtedly the value of cultivation is recognized; but on many farms it is not carried out. Climatic conditions bring about great diff.culties, in this regard, particularly with the late-planted crop. Many soils can not be worked properly when either too wet or too dry, and as a consequence the cane is left to suffer. However, it is common experience that the man who cultivates well is the man who reaps the reward.

I have found by extensive experiments at Greenhills, during the past season, that both the eggs and the young grubs are considerably injured by even shallow cultivation, for they are located near the surface in December. The common cultivators, reaching to a depth of about six inches, are satisfactory for this work; though I got somewhat better results by using a pony-plow, which got in closer to the roots.

In order to be effective this work must start at the time the beetles begin to emerge, and be continued, going over the ground every fortnight while they are on the wing. Normally, this would mean about four cultivations, which would mean no extra work in the case of late cane. I have advocated September-()ctober planting on grubbysoils, where they are well drained, so as to facilitate this cultivation during the flight of the beetles; the plants are then small enough so that the implements can get well under them.

We have had encouraging results in the use of arsenic for the destruction of the grubs. I found that by using arsenious acid (white arsenic) with Greenhill's soil in pots, that full grown grubs were quickly destroyed by ingesting it,- - all of them dying in one to four days. The quantity used was approximately what would amount to about 20 pounds per acre. I should state that only sifted soil and arsenic were placed in the pots, so that it was demonstrated that the grubs were destroyed by feeding on the poisoned humus of the soil.

Arsenic was used on our experimental plots at Meringa, in varving proportions and combinations; the best results apparently being from the use of the poison placed in the drill with the plants. In this case 20 pounds was mixed with 5 cwt. of meatworks manure per acre. The cane came along splendidly, with no sign of grub-injury, while several of the other plots showed more or less infestation.

Apparently the most satisfactory and far-reaching remedy, however, is the removal of all feeding trees, within a radius of about half a mile of infested rane areas. Investigation has demonstrated that once 
this is done the land becomes immune. This fact is particularly noticeable in the older districts, like the Herbert River and Goondi, where all the land was once more or less infested. Now that the clearing has been far extended, all of the older fields are immune; the only infestation being on the lands laying near the feeding trees. Hence we might justly conclude, that by concerted effort, many of the infested lands could be freed of this pest forever.

\section{('ONCLUSION}

As would appear from the above, the outlook is rather encouraging, in spite of the fact that the investigation has been carried on under many difficultics. It has been real pioneering. The spirit of unrest makes it hard to get the backing that a problem of such magnitude requires.

Practical results can only come from extensive application in the field. Already this is started in a small way, but it will take several years of conscientious investigation to bring about conclusive results.

\section{A SUCCESSFUL METHOD OF BREEDING PARASITES OF WHITE GRUBS}

By J. F. Iluingwonth, Gordonvale, near Cairns, North Queensland

Since Scarabæid beetles are found probably more abundantly in Australia than in any other part of the world, we naturally find their parasites well developed. Among these parasites numerous wasps have been recorded - about 50 species, according to Froggatt ${ }^{1}$ have been described from Australia. I have come in contact with only three of the principal ones, in my investigation of the several species of white grubs that attack sugar cune in North Queensland.

In order to know more definitely the habits of these friendly insects and to try to learn something of the relation of their hyperparasites, I instigated breeding work in the laboratory in 1917, using our two most abundant specics (Campsomeris tasmaniensis and C. formosus).

My assistant, Mr. E. Jarvis, carried out most of the work, since my time was largely oceupied in the field. At the time that the breeding was started, in December, the wasps were very numerous, flying over grub-infested lands near our Station. From these I collected several females, and found them very amenable to handling in small cages. When placed in covered tins, holding about half-a-pint of soil, they "dug themselves in" at once. Our usual practice was to place a grub in each of these tins, removing it whenever an egg was found attached

\footnotetext{
1 Australian Insects.
} 